Selcuk Journal of Agriculture and Food Sciences

http://sjafs.selcuk.edu.tr/sjafs/index

Research Article
SJAFS

(2021) 35 (2), 115-124

e-ISSN: 2458-8377

DOI:10.15316/SJAFS.2021.237

\title{
Early Detection of Mastitis by Using Infrared Thermography in Holstein- Friesian Dairy Cows Via Classification and Regression Tree (CART) Analysis
}

\author{
iD Gizem COŞKUN ${ }^{1}$, id İbrahim AYTEKİN ${ }^{1, *}$ \\ ${ }^{1}$ Selçuk University, Faculty of Agriculture, Department of Animal Sciences, Konya, Turkey
}

\begin{tabular}{l}
\hline ARTICLE INFO \\
\hline Article history: \\
Received date: 26.04 .2021 \\
Accepted date: 14.06 .2021 \\
\hline
\end{tabular}

Keywords:

Thermal Camera

Infrared ThermographyTechnology

Mastitis

Somatic Cell Count

California Mastitis Test

Dairy Cattle

CART analysis

\begin{abstract}
Subclinical mastitis is an important udder disease that negatively affects both the animal health and reduces profitability in dairy farms. The increasing performance of thermal cameras over time and their usability in different areas increase their use in livestocks. Infrared thermography (IRT) technology is a noninvasive method that can estimate the surface temperature of objects. The objective of this study was to evaluate early detection of mastitis in HolsteinFriesian dairy cattle by using both udder surface temperatures (Tmax) from images obtained with the help of a FLIR One Pro thermal camera and some parameters such as Lab (CIE L*, $\left.a^{*}, b^{*}\right)$, HSB (Hue, Saturation, Brightness), RGB (Red, Green, Blue) by processing thermal images with the help of ImageJ program via classification and regression tree (CART) analysis. According to California Mastitis Test CMT by using CART analysis in this study, $64.9 \%$ of cows with udder surface temperature lower than 38.85 were healthy, and $73.3 \%$ of cows higher than 38.85 were determined as unhealthy. As for SCC, $77.6 \%$ of cows with udder surface temperature lower than 38.65 were healthy and $58.6 \%$ of cows with higher than 38.65 were determined as unhealthy. The areas under ROC (AUC) were found to be statistically significant in the diagnosis of subclinical mastitis. $(\mathrm{P}<0.01)$ The sensitivity and specificity of the CART algorithm for CMT and SCC diagnostic tests were $85.42 \%, 81.48 \%$ and $90.20 \%, 80.39 \%$, respectively. There was no significant difference between SCC and CMT tests in the area under the ROC curve $(\mathrm{P}>0.05)$. As a result, IRT technology can be used as a useful diagnostic tool in the early detection of mastitis.
\end{abstract}

\section{Introduction}

Inadequate and unbalanced nutrition is one of the major problems for humanity. With an essential role in healthy and balanced nutrition, milk is a unique nutrient at every stage of human life. The quality of milk required for food safety is linked to udder health in cows. For this reason, the first production step plays a key role for healthy milk (Aytekin et al 2018). Mastitis is considered as an economically important udder disease, especially in its subclinical form (Kaşıkçı et al 2012). Miller et al. (1993) stated that in dairy cattle it results in severe economic losses from reduced milk production, treatment cost, increased labor, milk withheld following treatment and premature culling (Sharif et al 2009). Wide variation in the mastitis in a herd is attributable to genetic (herd, breed etc.) and nongenetic factors (parity, season, age, calving month, calving year, lactation stage etc.). Also, udder and teat morphology can also affect the mastitis level of the dairy cows (Uzmay et al 2003). Morover, cow cleanli-

\footnotetext{
*Corresponding author email: aytekin@selcuk.edu.tr
}

ness is important for providing hygienic milk production and the welfare of dairy cows (Aytekin et al 2021).

Monitoring of mastitis program is important for the udder health status of the herd and the quality of the raw milk in the herd. Monitoring udder health and milk quality can be routinely determined by evaluating the somatic cell count (SCC). The somatic cell count of uninfected mammary glands should be less than 200,000 cells/mL (Schukken et al 2003). In addition, the california mastitis test (CMT), which subjectively estimates the somatic cell number indirectly, is widely used in enterprises. CMT solution forms a gel by breaking down the cell membrane of leukocytes or epithelial cells in the milk sample and allowing the DNA to react with the test reagent. The higher the number of nucleated cells in the milk, the higher the gelation rate (Koçyiğit et al 2016). In addition to these methods, several different analytical methods such as White Side Test (WST), Catalase Test, Wisconsin Mastitis Test (WMT), breed method, coultercounter, DNA filter method and integrated fluorescent microscope methods have been used, as well as electrical conductivity, milk color sensor devices and biochemical analysis (Baştan et al. 1997; Yağc1 2008; Kaşıçcı et 
al. 2012; Aytekin and Boztepe 2013; Aytekin et al. 2018). In short, early diagnosis of mastitis is very important in terms of minimizing economic losses in enterprises, protecting the welfare of animals and producing quality milk. Infrared thermography (IRT) is an important and noninvasive method that can estimate the skin surface temperature of examining physiological changes and responses (Hovinen et al. 2008; Jones and Plassmann 2002; Byrne et al. 2018).

Thermal cameras first started to be used in military areas and later became widespread in industrial areas (Polat et al. 2010). Recently, IRT has been used frequently for early diagnosis of some diseases such as mastitis (Bitman et al. 1984; Porcionata et al. 2009; Polat et al. 2010; Sathiyabarayhi et al. 2016 and Golzarian et al. 2017), lameness (Eddy et al. 2001; Alsaaod et al. 2012; Stokes et al. 2012; Gianesella et al. 2018; Fabbri et al. 2020), östrus detection (Hurnik et al. 1985; Talukder et al. 2014; Marquez et al. 2019), sperm quality (Menegassi at al. 2015), pregnancy (Jones at al. 2005; Bowers et al. 2009; Radigonda et al. 2017), heat stress (Daltro et al. 2017; Unruh at al. 2017), prediction of live weight (Stajnko et al. 2008; Stanjko et al. 2010; Kuzuhara et al. 2015), measurement of body temperature (Cangar et al. 2008; Nascimento et al. 2011), milking machine performance (Castro-Costa et al. 2014; Tangorra et al. 2019), animal welfare (Stewart et al. 2005; Abudabos et al. 2013), in the livestocks. Furthermore, its small size provides portability and ease of use, while being able to use the image remotely without physical contact with the animal provides great convenience as a safe evaluation method and detecting diseases in the livestocks (Fabbri et al. 2020). First of all, the main advantages of the thermal camera are that it is a remote, non-contact and non-invasive method, absolutely painless, fast and reliable, a real time technique, enable monitoring of dynamical variations of temperature and also has no harmful radiation effects (Lahiri et al. 2012). Moreover, in thermal imaging, the hottest areas appear red or white color, while the coldest areas appear blue or black color (Colak et al. 2008; Polat et al. 2010; Sathiyabarathi et al. 2016).

CART is a non-parametric method that analysis complex relations between dependent and independent variables with group effects by classifying the sample into homogenous sub-groups and entering the model (Kayri and Boysan 2008). Classification and regression tree (CART) practiced for nominal, ordinal, and continuous variables is one of the data-mining algorithm used for constructing the decision tree (Çelik et al. 2016). Furthermore, CART has an advantage is that the analysis technique is free from the presumptions of multiple regression analysis such as normality, homogeneity, and interdependency of observations for parametric methods are ignored (Kayri and Boysan 2008).
The objective of thepresent study is to evaluate the potential benefit ofthe thermal camera as a noninvasive tool by CART analysis in the early detection of mastitis in Holstein-Friesian dairy cattle.

\section{Materials and Methods}

\section{Animals and Milking managements}

The animal material of this study consisted of Holstein-Friesian dairy cows reared in a private dairy cattle farm in Karapinar district of Konya province. Dairy cows were fed ad libitum with TMR containing a mixture of concentrated feed and forage such as straw, alfalfa, fescue grass, corn silage and alfalfa silage. Milking was carried out 3 times a day by two milkers in the enterprise. Milking management and hygiene rules were implemented in the enterprise. Dairy cows milked three times daily in a $2 \times 15$ parallel milking parlour with EcoHerd management program. Milk sampling, udder photography and animal breeding practices were performed according to the animal welfare rules stated in Article 9 in government law in Turkey (No. 5996).

\section{Milk sampling}

Milk samples of 102 head primiparous HolsteinFriesian dairy cows were taken by using sampling equipment during milking time in order to represent homogeneous of all milk. The milk samples were cooled immediately and transported in cooler boxes to the Animal Biotechnology laboratory of the Department of Animal Science within $2 \mathrm{~h}$. California Mastitis Test (CMT) and Somatic Cell Count (SCC) were determined from milk samples taken into falcone tubes $(50 \mathrm{~mL})$ in the morning milking.

\section{Somatic Cell Count (SCC) and Electrical Conductivity} (EC)

Somatic Cell Counts SCC (cell/ml) from milk samples were measured using NucleoCounter SCC-100 (Chemometec, Denmark). The numbers of cells $/ \mathrm{ml}$ in the SCC counter are above limit of 10,000 cells $/ \mathrm{ml}$ and below limit of 2,000,000 cells/mL. Milk's electrical conductivity was obtained from the milking system sensor (ENGS, EcoHerd, Version 1.01).

\section{California mastitis test (CMT) analysis}

CMT scores of all samples were determined by using a same solution, equipment and expert. Milk samples were homogeneously taken from each cow at the milking by using milk sampler. Then, milk samples were placed in a plastic test paddle, divided into 4 separate wells, in order to determine mastitis status. CMT solution was added on the milk samples taken and after mixing same direction in an oval shape for about 20 seconds, it was diagnosed by the expert (Shitandi and Kihumbu 2004). 


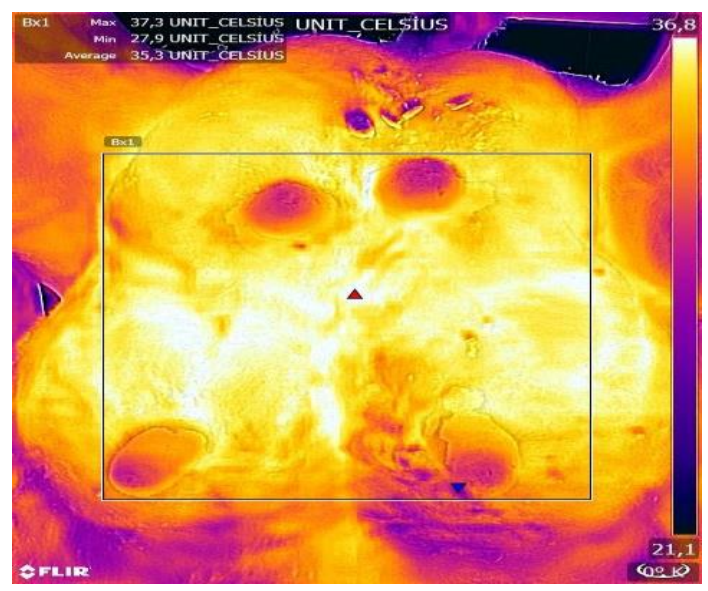

Figure 1

Thermal and normal udder images

Infrared Thermography and digital images processing

Thermal images were taken under the udder using FLIR One Pro before milking in the enterprise with parallel milking parlour. FLIR One Pro operates at $0^{\circ} \mathrm{C}$ $-35^{\circ} \mathrm{C}\left(32^{\circ} \mathrm{F}-95^{\circ} \mathrm{F}\right)$ and can detect temperatures from $-20^{\circ} \mathrm{C}-400^{\circ} \mathrm{C}\left(-4^{\circ} \mathrm{F}-752^{\circ} \mathrm{F}\right)$. Udder skin surface temperatures were determined using the FLIR tools program after taking the infrared thermal images. Lab (CIE L*, a*, b*), HSB (Hue, Saturation, Brightness) and RGB (Red, Green, Blue) values were determined by processing digital images with the Image-j program (Rasband, 1997). It represents the color change of $\mathrm{L}^{*}$ between 0 (black) and 100 (white), green (-a) to red $(+a)$ and blue (-b) to yellow (+b) in the digital image processing (CIE 1978). H, S and B color spaces are defined as Hue $(\mathrm{H})$, saturation $(\mathrm{S})$ and brightness $(\mathrm{B})$, respectively. The use of the HSB color model is closer to the human eye's potential to see than the RGB model. The HSB color model is generally used for the separation of colored objects. Hue $(\mathrm{H})$ is the portion of color that varies between 0 and 1 (or 0 to $360^{\circ}$ ) that corresponds in the position of the colorcylinder. Saturation $(\mathrm{S})$ represents the amount of gray from 0 (gray) to $100 \%$ (main color) in the color. The brightness (V) indicates the brightness or intensity of the color ranging from 0 (Black) to $100 \%$ (brightest) (Joblove and Greenberg 1978). A thermal image taken under the udder using FLIR One Pro before milking are given in Figure 1.

\section{Statistical analysis}

CMT and CSCC such as subclinical mastitis diagnosis tests were binary dependent variables such as healthy and unhealthy. Also, udder skin surface temperatures, electrical conductivity and image processing parameters (L, a, b, Hue, Saturation, Brightness, Red, Green and Blue) were independent variables. In order to create the decision tree structure, threshold value for healthy or unhealthy of animals assumed to be a 200,000 cells/mL for CSCC and negative for CMT. That is, others were coded as unhealthy.There are many algorithms in decision treesin literature.CART (Classification and Regression Tree) data mining algorithm (Breiman et al. 1984) was used in this study. CART is

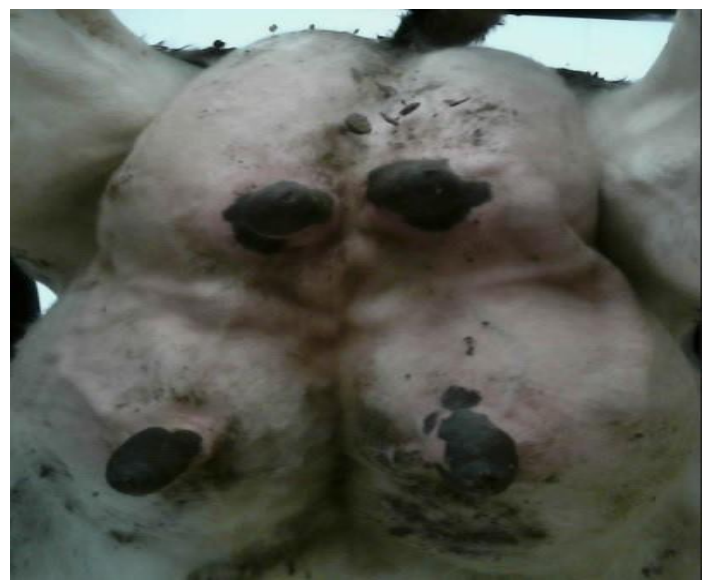

a tree-based algorithm that is not in a mathematical form. It creates a binary classification tree by dividing a subset into smaller subsets. CART algorithm for decision tree-based diagnosis of mastitis has been preferred due to binary node splitting rule and visual results much easier to interpret recently. In the 10-fold cross-validation, the whole data set (102 records) was randomly divided into 10 approx. equal parts of 10 records, from which nine were used to train a given type of a prediction model and one served as an independent test set. This procedure was repeated 10 times (Eyduran et al. 2017; Aytekin et al. 2018). The Gini index was used as the division criterion. Accuracy, sensitivity and specificity formulas were calculated according to Mikail and Keskin (2015) and Aytekin et al. (2018). Confusion table for the classifier algorithms was given in Table 1.

Table 1

Confusion table for the classifier algorithms

\begin{tabular}{llcc}
\hline & \multicolumn{3}{c}{ Predicted as } \\
\cline { 4 - 4 } & & Unhealthy & Healthy \\
\hline \multirow{2}{*}{ Observed } & Unhealthy & $\mathrm{X}$ & $\mathrm{Y}$ \\
\cline { 2 - 2 } & Healthy & $\mathrm{W}$ & $\mathrm{Z}$ \\
\hline
\end{tabular}

Accuracy $=(\mathrm{X}+\mathrm{Z}) /(\mathrm{X}+\mathrm{Y}+\mathrm{W}+\mathrm{Z})$

Sensitivity $=\mathrm{X} /(\mathrm{X}+\mathrm{Y})$

Specificity $=\mathrm{Z} /(\mathrm{W}+\mathrm{Z})$

Error proportion $=1-$ Accuracy

$s e_{A U C}=\sqrt{\frac{A U C(1-A U C)+\left(n_{A}-1\right)\left(q 1-A U C^{2}\right)+\left(n_{B}-1\right)\left(q 2-A U C^{2}\right)}{n_{A} n_{B}}}$

$n_{A}=X+W \quad$ and $n_{B}=Y+Z$

$q 1=\frac{A U C}{2-A U C}$ and $q 2=\frac{2 A U C^{2}}{1+A U C}$

In the above equation represent, $\mathrm{X}, \mathrm{Z}, \mathrm{Y}$ and $\mathrm{W}$ represent the numbers of true positive, true negative, false positive and false negative, respectively and formula was used from developed by Hanley and McNei (1982) to determine AUC (AUCse). Pairs of algorithms in area under ROC curve were compared on the basis of $\mathrm{z}$ test. IBM SPSS 23 (IBM Corporation, Armonk, New York, USA) statistical package program was used for CART algorithm for decision tree-based diagnosis of mastitis. 
MedCalc trial version 19.5.1 was used to calculate the area under the ROC curve and its comparison (AUC) and compare the algorithm pairs in the field.

\section{Results and Discussion}

An infrared camera detects the thermal radiation emitted by a surface and the intensity of the emitted radiation is converted to temperature. Also, IRT can be static or dynamic. Infrared radiation emitted by a surface depends on the experimental conditions such as moisture, airflow and surrounding temperature. Hence, it is an absolute necessity for thermography experiments, especially in medical applications where temperature changes are within a few degrees, to be performed in controlled environments (Lahiri et al. 2012). Since the lactating cows were milked in the same environmental conditions in the milking parlor, the factors affecting the thermal image such as moisture, airflow and surrounding temperature had the same effect on all animals in this study.

Classification table of the CART algorithmwas given in Table 2. Classification performances for each

Table 2

Classification table of the CART algorithm

\begin{tabular}{llccc}
\hline \multirow{2}{*}{ Dependent Variable } & & \multicolumn{3}{c}{ Predicted } \\
\cline { 2 - 5 } & Observed & Unhealthy & Healthy & Correct $(\%)$ \\
\hline \multirow{2}{*}{ CSCC } & Unhealthy & 41 & 10 & 80.4 \\
& Healthy & 5 & 46 & 90.2 \\
\hline \multirow{3}{*}{ CMT } & Overall (\%) & 45.1 & 54.9 & 85.3 \\
& Unhealthy & 44 & 10 & 81.5 \\
& Healthy & 7 & 41 & 85.4 \\
\hline
\end{tabular}

Table 3

Classification performances for each diagnosis test of CART algorithm

\begin{tabular}{|c|c|c|c|c|c|c|}
\hline Methods & Sensitivity & Specificity & AUC & Accuracy & $\mathrm{P}$ & $\begin{array}{c}\text { Pairwise com- } \\
\text { parison of AUC } \\
\text { P-value }\end{array}$ \\
\hline CSCC & 0.9020 & 0.8039 & $0.8530 \pm 0.0351^{\mathrm{A}}$ & 0.8530 & 0.000 & \multirow{2}{*}{0.8279} \\
\hline CMT & 0.8542 & 0.8148 & $0.8340 \pm 0.0371^{\mathrm{A}}$ & 0.8330 & 0.000 & \\
\hline
\end{tabular}

A, The difference between the algorithms with letter in CMT or CSCC column is not significant (comparison of the subclinical mastitis diagnostic tests)

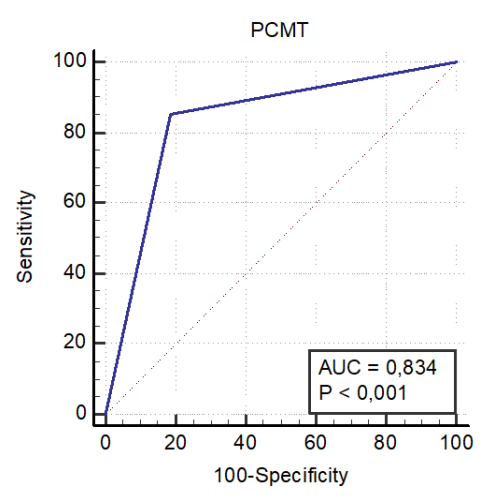

CMT

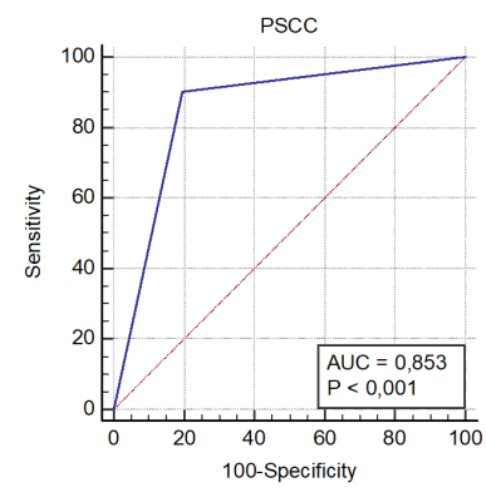

CSCC

Figure 2

ROC curve for each diagnosis test of CART algorithm 
Classification tree diagram constructed by CART for CSCC test was given Figure 3. According to Figure 3 , half of the 102 head Holstein-Friesian dairy cattle were classified as healthy and the other half as unhealthy in node 0 . Node 0 was split into two smaller subgroups (Nodes 1 and 2) by electrical conductivity. In the first depth of the classification tree structure, cows whose electrical conductivity had 8.60 or lower in their milks were healthy at a percentage of 64.1 (Node1), but cows whose electrical conductivity had greater than 8.60 in their milks were characterized as unhealthy at the percentage of 95.8 (Node 2). Since the homogeneity is achieved at node 2 (split complete), the terminal node had been reached.

Cows in node 1 were classified into two smaller subgroups (Nodes 3 and 4) according to thermal temperature predictor. Cows whose electrical conductivity had greater than 8.60 in their milks and whose skin surface temperature had greater than 38.65 in their udders were unhealthy at the percentage of 56.8 (Node 4).

As for node 4, cows were classified into two smaller subgroups (Nodes 7 and 8) according to saturation predictor. While $69.2 \%$ of cows were healthy (Node 7) based on electrical conductivity $(\leq 8.60)$, thermal temperature $(>38.65)$ and saturation $(\leq 181856.5)$ predictors, $81.2 \%$ of cows were unhealthy (Node 8 ) based on electrical conductivity $(\leq 8.60)$, thermal temperature $(>$ $38.65)$ and saturation (> 181856.5) predictors.

Considering node 3 , cows were classified into two smaller subgroups (Nodes 5 and 6) according to ther- mal temperature predictor. Indeed, $65.5 \%$ of the cows (Node 5) were found to be healthy if the electrical conductivity value had $\leq 8.60$ (Node 1 ) and the thermal temperature value had $>38.65$ (Node 3 ) in addition to the udder skin surface temperatures being $\leq 37.95$. In addition to the previous nodes ( 1 and 3 ), similarly, 95\% of cows (Node 6) with udder skin surface temperatures greater than 37.95 were found to be healthy. In other words, $95 \%$ of cows were understood to be healthy when udder skin surface temperature range was between $>37.95$ and $\leq 38.65$. This results also showed similarities with the udder skin surface temperature values $38.8 \pm 1{ }^{\circ} \mathrm{C}$ in study made of Bitman et al. (1984) and $37.61^{\circ} \mathrm{C}$ in study made of Sathiyabarathi et al. (2018).

Node 5 was divided into two subgroups as Node 9 and 10 according to the Hue value. In addition to node 5 , while $100 \%$ of cows having hue $\leq 64783.0$ were found healthy (Node 9), $47.6 \%$ of cows having hue > 64783.0 were classified as unhealthy (Node 10).

Node 10 via CART algorithm was divided into two subgroups as node 11 and node 12 according to the $\mathrm{L}$ value. In addition to predictors down to node 10 , while $100 \%$ of cows with $\mathrm{L}$ value $\leq 59788.0$ were healthy (Node 11), 62.5\% of cows with L> 59788.0 were classified as mastitis (Node 12). Classification tree diagram constructed by CART for CMT test was presented Figure 4. According to Figure 4, 102 head HolsteinFriesian dairy cattle as healthy and unhealthy were classified $52.9 \%$ and $47.1 \%$, respectively in node 0 .

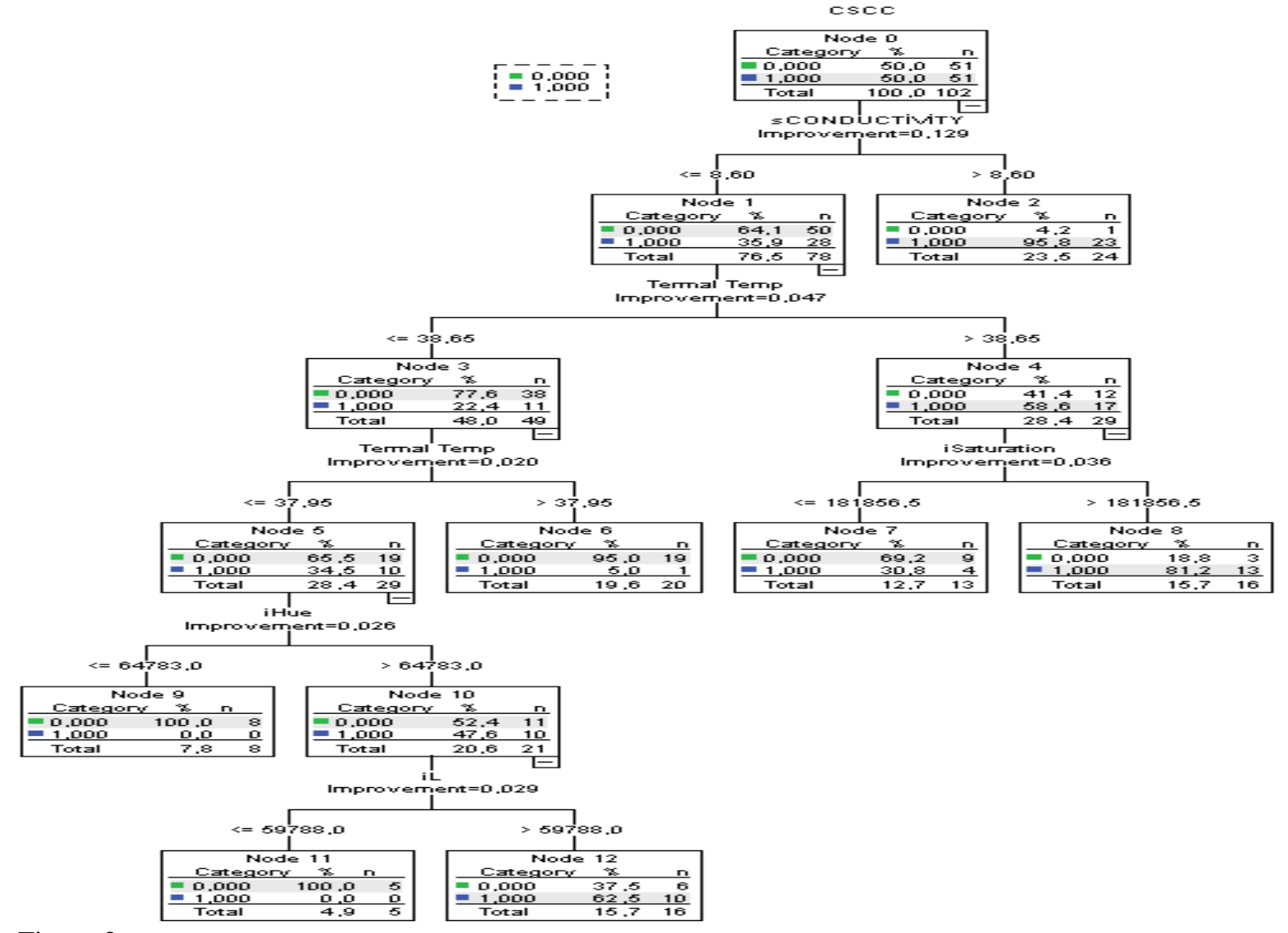

Figure 3

Classification tree diagram constructed by CART for CSCC test 
Again as in CSCC, cows in node 0 were classified into two smaller subgroups (Nodes 1 and 2) according to electrical conductivity predictor in classification tree diagram constructed by CART for CMT test. In the first depth of the classification tree structure, cows whose electrical conductivity had 8.80 or lower in their milks were healthy at a percentage of 63.9 (Node1), but cows whose electrical conductivity had greater than 8.80 in their milks were characterized as unhealthy at the percentage of 94.7 (Node 2). Since the homogenei- ty is achieved at node 2 (split complete), the terminal node had been reached.

Cows in node 1 were classified into two smaller subgroups (Nodes 3 and 4) according to red predictor, one of the parameters obtained by processing thermal image. $53.8 \%$ of the cows (Node 3) were found to be healthy if the electrical conductivity value had $\leq 8.80$ (Node 1) and the redness value of thermal temperature value had $\leq 226603.5$ (Node 3). As seen on Note 4 , $80.6 \%$ of cows with red value $>226603.3$ were found to be unhealthy.

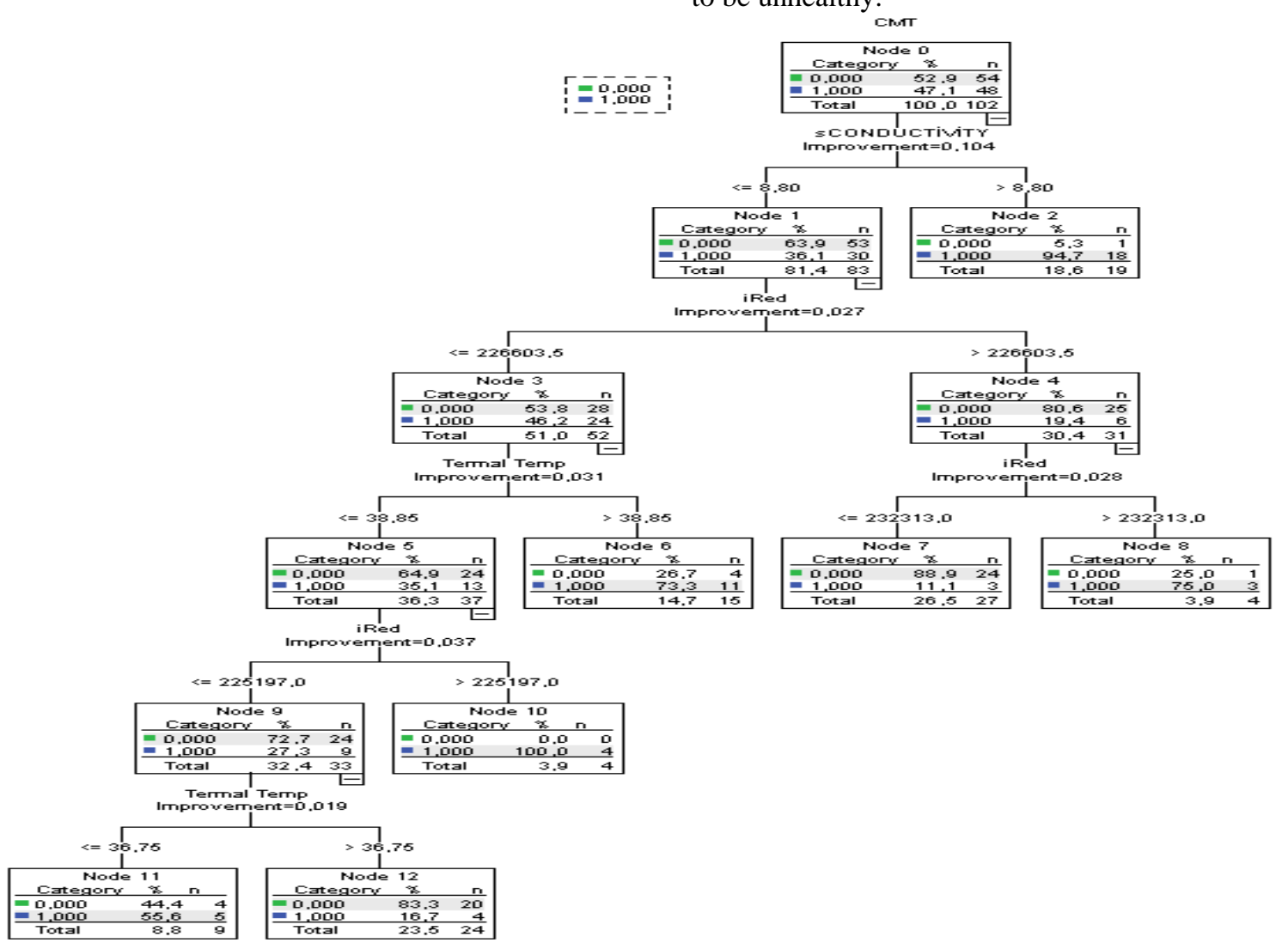

Figure 4

Classification tree diagram constructed by CART for CMT test

In node 4 , while $88.9 \%$ of cows with electrical conductivity both with a value of $\leq 8.80$ and with a range of $226603.5<$ red $\leq 232310.0$ in the node 7 were found to be healthy, $75 \%$ of cows with values of electrical conductivity $(\leq 8.80)$ and red $(>226603.3$ and $>$ 232313.0) in the node 8 were classified as unhealthy.As for node 3, two subgroups as node 9 and 10 according to the udder skin surface temperature were classified. In node 5, 64.9\% of cows with electrical conductivity with a value of $\leq 8.80$, red with a value of $\leq 226603.5$ and thermal temperature with a value of $\leq$ 38.85 were found to be healthy. Unlike node $5,73.3 \%$ of cows with values thermal temperature with a value of $>38.85$ were classified as unhealthy in node 6 .

Cows in node 5 were classified into two smaller subgroups (Nodes 9 and 10) according to red predictor. $72.7 \%$ of the cows (Node 9) having electrical conductivity $\leq 8.80$, red $\leq 226603.5$, thermal temperature $\leq$ 38.85 and red $\leq 225197.0$ were found to be healthy, As seen on Note $10,80.6 \%$ of cows having red $>225197$ was found to be unhealthy.

As for node 9 , node 10 and 11 subgroups according to the udder skin surface temperature were classified. In addition to the classified predictors down to these subgroups, $55.6 \%$ of cows having udder skin surface temperature $\leq 36.75$ and $83.3 \%$ of cows having udder skin surface temperature $>36.75$ were found to be unhealthy and healthy, respectively.

There is a great deal of literature on both individual and combined use of diagnostic tests such as somatic cell count, California mastitis test and electrical conductivity value in the diagnosis of subclinical mastitis in dairy cattle until today (Baştan et al. 1997; Aytekin and Boztepe 2013; Aytekin and Boztepe, 2014; Aytekin et al. 2018; Aytekin et al. 2021). It has been proven in recent studies that the thermal camera is a useful tool in both diagnostic and physiological evaluations (Lahiri et al. 2012). The increasing performance of thermal 
cameras over time and their usability in different areas makes their use in livestocks very popular. IFT has been used in many areas in livestock until today, and some studies such as Bitman et al. (1984), Berry et al. (2003), Hovinen et al. (2008), Porcionata et al. (2009), Polat et al. (2010), Metzner et al. (2014), Sathiyabarayhi et al. (2016), Pampariene et al. (2016), Golzarian et al (2017), Byrne et al. (2018), Juozaitienë et al. (2018) have been conducted for the diagnosis of mastitis in dairy cattle.

Bitman et al. (1984) reported that body and udder temperature in dairy cattle was $38.8 \pm 1^{\circ} \mathrm{C}$. In a study investigating the use of thermal camera for early detection of mastitis and its relation with other mastitis tests, udder surface temperatures of healthy, subclinical and clinical mastitis groups were 37.22, 38.08 and 38.25, respectively (Sathiyabarayhi et al. 2016). Researchers stated that thermal camera is a rapid and non-invasive technique for early detection of mastitis in dairy cattle. According to CMT by using CART analysis in this study, $64.9 \%$ of cows with udder surface temperature lower than 38.85 were healthy, and $73.3 \%$ of cows higher than 38.85 were determined as unhealthy. According to SCC, $77.6 \%$ of cows with udder surface temperature lower than 38.65 were healthy, and $58.6 \%$ of cows with higher than 38.65 were determined as unhealthy. The accuracy of these two systems is as high as $83.3 \%$ and $85.3 \%$, respectively. Results obtained in the current study Bitman et al (1984) and Sathiyabarayhi et al. (2016) is compatible with the results reported.

Polat et al. (2010) compared the ability of thermal camera to detect mastitis with somatic cell count and california mastitis test results. The study showed that the sensitivity and specificity of the thermal camera (95.6\% and $93.6 \%$, respectively) did not differ from those of CMT $(88.9 \%$ and $98.9 \%)$, there was a positive correlation between udder surface temperature and SCC $(r=0.73)$ and CMT $(r=0.86)$. The surface temperatures of udder lobes with negative $+1,+2$ and +3 CMT scores were determined as $33.23,34.64,35.75$ and 36.27 , respectively. The researchers reported that the thermal camera was successful in diagnosing subclinical mastitis. In the current research, the reason of udder surface temperature higher than study conducted by Polat et al. (2010) can be due to limiting factors use of thermal camera.

On the contrary, in the study was carried for detect subclinical mastitis at early stage, Porcionata et al. (2009) stated that the diversity was important between different udder regions, also somatic cell count did not affect udder surface temperature $(\mathrm{P}>0.05)$. For this reason, the researchers stated that the thermal camera cannot be used in the diagnosis of subclinical mastitis. Golzarian et al. (2017) investigated the use of thermal camera in determining mastitis. Thermal image results were compared with SCC and CMT test results. They reported that the accuracy of this system is as low as $57.3 \%$. Consequently, Porcionata et al. (2009) and Golzarian et al. (2017) literature results and current study results do not compatible. This can be due to the lack of attention to factors that limit the use of the thermal imager. Environmental factors such as humidity, temperature, ventilation, wind, and sunlight significantly affect the imaging results. In addition to environmental factors, it is possible to minimize the errors in imaging when important issues such as the distance between the animal and the thermal camera, the angle of the thermal camera, the cleaning of the udder to be image and the physical activity of the animals before imaging (Cilulko et al. 2013; Coşkun and Aytekin, 2020).

\section{Conclusion}

The most important step in the sustainability of quality milk production and animal welfare in herd management is to know the factors that cause mastitis and to take the necessary precautions. Otherwise, severe economic losses from reduced milk production, treatment cost, increased labor, milk withheld following treatment and culling may happen in herd. In the present study, the results showed that there was a statistically significant relationship between udder skin surface temperature obtained via IRT technology and diagnostic tests such as SCC and CMT in the early detection of mastitis by CART algorithm $(\mathrm{P}<0.00)$. Accuracies of the CART algorithm for CSCC and CMT diagnostic test had high rate such a $85.30 \%$ and $83.30 \%$, respectively.

In addition to being a fast, effective and noninvasive tool, IRT technology is sensitive enough to detect minor temperature changes on the breast surface caused by subclinical mastitis. Consequently, according to the classification tree diagram constructed by CART for CSCC and CMT diagnostic tests, the current study results showed that the use of thermal cameras in the early diagnosis of subclinical mastitis is a successful detection method. In addition, it can be stated that their reliability will increase even more when used in combination with other mastitis diagnostic methods by paying attention to the factors limiting the use of thermal cameras. Also, since IRT technology is likely to be used more in the livestock sector in the near future with the technological developments over time, more comprehensive studies should be needed.

\section{Acknowledgements}

This research was supported as a part of Gizem Coşkun's master thesis by a grant from The Scientific Research Project Office of Selcuk University, Turkey (Project No: 20201066). We are thankful to Gökcan Dairy Cattle Agricultural Enterprise for providing the material used in this study.

\section{References}

Abudabos AM, Samara EM, Hussein EO, Al-Ghadi MAQ, Al-Atiyat RM (2013). Impacts of stocking 
density on the performance and welfare of broiler chickens. Italian Journal of Animal Science 12(1): e11.

Alsaaod M, Büscher W (2012). Detection of hoof lesions using digital infrared thermography in dairy cows. Journal of Dairy Science 95(2): 735-742.

Aytekin İ, Boztep S (2013). Associations of Pit-1 gene polymorphism with milk yield and composition traits in brown swiss cattle. Journal of Animal Plant Science 23(5): 1281-1289.

Aytekin İ, Boztepe, S (2014). Somatic cell count, importance and effect factors in dairy cattle. Turkish Journal of Agriculture-Food Science and Technology 2(3): 112-121.

Aytekin İ, Eyduran E, Keskin İ (2018). Detecting the relationship of California mastitis test (CMT) with electrical conductivity, composition and quality of the milk in Holstein-Friesian and brown swiss cattle breeds using cart analysis. Fresenius Environmental Bulletin 27(6): 4559-4565.

Aytekin I, Altay Y, Boztepe S, Keskin İ, Zulkadir U (2021). The effect of body cleanliness (hygiene) score on some criteria used in the detection milk quality in dairy cattle. Large Animal Review 27(2): 69-74.

Baştan A, Kaymaz M, Findık M, Erünal N (1997). İneklerde subklinik mastitislerin elektriksel iletkenlik, somatik hücre sayısı ve california mastitis test ile saptanması. Ankara Üniviversitesi Veteriner Fakültesi Dergisi 44(1): 1-6.

Berry RJ, Kennedy AD, Scott SL, Kyle BL, Schaefer AL (2003). Daily variation in the udder surface temperature of dairy cows measured by infrared thermography: Potential for mastitis detection. Canadian Journal of Animal Science 83(4): 687-693.

Bitman J, Lefcourt A, Wood DL, Stroud B (1984). Circadian and ultradian temperature rhythms of lactating dairy cows. Journal of Dairy Science 67(5): 1014-1023.

Bowers S, Gandy S, Anderson B, Ryan P, Willard S (2009). Assessment of pregnancy in the lategestation mare using digital infrared thermography. Theriogenology 72(3): 372-377.

Breiman L, Friedman JH, Olshen RA, Stone CJ (1984). Classification and regression trees. Belmont, CA: Wadsworth. International Group 432: 151-166.

Byrne DT, Berry DP, Esmonde H, McHugh N (2018). Investigation of the relationship between udder quarter somatic cell count and udder skin surface temperature of dairy cows measured by infrared thermography Journal of Animal Science 96(10): 4458-4470.

Cangar Ö, Aerts JM, Buyse J, Berckmans D (2008). Quantification of the spatial distribution of surface temperatures of broilers. Poultry Science 87(12): 2493-2499.
Castro-Costa A, Caja G, Salama AAK, Rovai M, Flores C, Aguiló J (2014). Thermographic variation of the udder of dairy ewes in early lactation and following an Escherichia coli endotoxin intramammary challenge in late lactation. Journal of Dairy Science 97(3): 1377-1387.

Cilulko J, Janiszewski P, Bogdaszewski M, Szczygielska E (2013). Infrared thermal imaging in studies of wild animals. European Journal of Wildlife Research 59 (1): 17-23.

CIE (1978). Recommendations on uniform color spaces, color di erence equations, psychometric color terms. Supplement No.2 to CIE publication No.15 (E.-1.3.1) Paris: Bureau Central de la CIE.

Colak A, Polat B, Okumus Z, Kaya M, Yanmaz LE, Hayirli A (2008). Early detection of mastitis using infrared thermography in dairy cows. Journal of Dairy Science 91(11): 4244-4248.

Coşkun G, Aytekin İ (2020). The use of thermal cameras in animal production and limiting factors its use. In: International Hazar Scientific Research Conference, 18-20 September 2020, Khazar University, Baku, Azerbaijan.

Çelik Ş, Söğüt B, Şengül T, Eyduran E, Şengül AY (2016). Usability of CART algorithm for determining egg quality characteristics influencing fertility in the eggs of Japanese quail. Revista Brasileira de Zootecnia 45(11): 645-649.

Daltro DDS, Fischer V, Alfonzo EPM, Dalcin VC, Stumpf MT, Kolling GJ, Silva MVGBD, McManus C (2017). Infrared thermography as a method for evaluating the heat tolerance in dairy cows. Revista Brasileira de Zootecnia 46(5): 374-383.

Eddy AL, Van Hoogmoed LM, Snyder JR (2001). The role of thermography in the management of equine lameness. The Veterinary Journal 162(3): 172-181.

Eyduran E, Zaborski D, Waheed A, Celik S, Karadas K, Grzesiak W (2017). Comparison of the predictive capabilities of several data mining algorithms and multiple linear regression in the prediction of body weight by means of body measurements in the indigenous beetal goat of Pakistan. Pakistan J. Zool., 49: 257-265.

Fabbri G, Fiore E, Piccione G, Giudice E, Gianesella, M, Morgante M, Armato L, Bonato O, Giambelluca S, Arfuso F (2020). Detection of digital and interdigital dermatitis in Holstein Friesian dairy cows by means of infrared thermography. Large Animal Review26(3): 113-116.

Gianesella M, Arfuso F, Fiore E, Giambelluca S, Giudice E, Armato L, Piccione G (2018). Infrared thermography as a rapid and non-invasive diagnostic tool to detect inflammatory foot diseases in dairy cows. Polish Journal of Veterinary Sciences 21(2): 299-305.

Golzarian MR, Soltanali H, Doosti Irani O, Ebrahimi SH (2017). Possibility of early detection of bovine mastitis in dairy cows using thermal images pro- 
cessing. Iranian Journal of Applied Animal Science 7(4): 549-557.

Hanley J.A, McNeil BJ (1982). The meaning and use of the area under a receiver operating characteristic (ROC) curve. Radiology 143(1): 29-36.

Hovinen M, Siivonen J, Taponen S, Hänninen L, Pastell M, Aisla AM, Pyörälä S (2008). Detection of clinical mastitis with the help of a thermal camera. Journal of Dairy Science 91(12): 4592-4598.

Hurnik JF, Webster AB, DeBoer S (1985). An investigation of skin temperature differentials in relation to estrus in dairy cattle using a thermal infrared scanning technique, Journal of Animal Science, 61(5), 1095-1102.

IBM Corp. Released, (2015). IBM SPSS Statistics for Windows, Versiyon 23.0. Armonk, NY: IBM Corp.

Juozaitienë V, Juozaitis A, Zymantiene J, Oberauskas V, Aniuliene A, Kajokiene L, Y1lmaz A, Simokaitiene A (2019). The effect of different levels of teatend hyperkeratosis on mammary infrared thermograph and mastitis in dairy cows. Ankara Üniversitesi Veteriner Fakültesi Dergisi 66: 21-26

Joblove GH, Greenberg D (1978). Color spaces for computer graphics. Proceedings of the 5th Annual conference on Computer Graphics and Interactive Techniques, 20-(5).

Jones BF, Plassmann P (2002). Digital infrared thermal imaging of human skin. IEEE Engineering in Medicine and Biology 21(6): 41-48.

Jones M, Denson A, Williams E, Dos Santos A, Graves K, Kouba A, Willar S (2005). Assessing pregnancy status using digital infrared thermal imaging in Holstein heifers. Journal Of Dairy Sclence 88: 4041.

Kaşıkçı G, Cetin Ö, Bingöl EB, Gündüz MC (2012) Relations between electrical conductivity, somatic cell count, California mastitis test and some quality parameters in the diagnosis of subclinical mastitis in dairy cows. Turkish Journal of Veterinary and Animal Sciences36(1): 49-55.

Kayri M, Boysan M (2008) Assesment of relation between cognitive vulnerability and depression's level by using classification and regression tree analysis.Hacettepe University Journal of Educatıon. 34: 168-177.

Koçyiğit R, Yılmaz O, Özenç E, Mehmet U (2016). Effect of some risk factors on subclinical mastitis in dairy cows. Kocatepe Veteriner Dergisi, 9(3), 185193.

Kuzuhara, Y., Kawamura, K., Yoshitoshi, R., Tamaki, T., Sugai, S., Ikegami, M., Yasuda, T. (2015). A preliminarily study for predicting body weight and milk properties in lactating Holstein cows using a three-dimensional camera system. Computers and Electronics in Agriculture 111: 186-193.

Lahiri BB, Bagavathiappan S, Jayakumar T, Philip J (2012). Medical applications of infrared thermogra- phy: a review. Infrared Physics \& Technology 55(4): 221-235..

Marquez HP, Ambrose DJ, Schaefer AL, Cook NJ, Bench CJ (2019). Infrared thermography and behavioral biometrics associated with estrus indicators and ovulation in estrus-synchronized dairy cows housed in tiestalls. Journal of dairy science, 102(5), 4427-4440.

Menegassi SRO, Barcellos JOJ, Dias EA, Koetz C, Pereira GR, Peripolli V, McManus C, Conazzi MEA, Lopes, FG (2015). Scrotal infrared digital thermography as a predictor of seasonal effects on sperm traits in Braford bulls. International Journal of Biometeorology 59(3): 357-364.

Metzner M, Sauter-Louis C, Seemueller A, Petzl W, Klee W (2014). Infrared thermography of the udder surface of dairy cattle: Characteristics, methods, and correlation with rectal temperature. The Veterinary Journal 199(1): 57-62.

Mikail N, Keskin İ (2015). Subclinical mastitis prediction in dairy cattle by application of fuzzy logic. Pakistan Journal of Agricultural Sciences 52: 11011107.

Nascimento GR, Nääs IA, Pereira DF, Baracho MS, Garcia R (2011). Assessment of broiler surface temperature variation when exposed to different air temperatures. Brazilian Journal of Poultry Science 13(4): 259-263.

Pampariene I, Veikutis V, Oberauskas V, Zymantiene J, Zelvyte R, Stankevicius A, Marciulionyte D, Palevicius P (2016). Thermography based inflammation monitoring of udder state in dairy cows: Sensitivity and diagnostic priorities comparing with routine California mastitis test. Journal of Vibroengineering 18(1): 511-521.

Polat B, Colak A, Cengiz M, Yanmaz LE, Oral H, Bastan A, Kaya S, Hayirli A, (2010). Sensitivity and specificity of infrared thermography in detection of subclinical mastitis in dairy cows. Journal of Dairy Science 93(8): 3525-3532.

Porcionato MAF, Canata TF, De Oliveira CE, Dos Santos, MV (2009). Udder thermography of gyr cows for subclinical mastitis detection. Revista Brasileira de Engenharia de Biossistemas 3(3): 251-257.

Radigonda VL, Pereira GR, da Cruz Favaro P, Júnior FAB, Borges MHF, Galdioli VHG, Júnior CK (2017). Infrared thermography relationship between the temperature of the vulvar skin, ovarian activity, and pregnancy rates in Braford cows. Tropical animal health and production 49(8): 1787-1791.

Rasband WS (1997). Image J. Bethesda, MD: National Institutes of Health, Available at http:/rsb.info.nih.gov/ij/.

Sathiyabarathi M, Jeyakuma S, Manimaran A, Jayaprakash G, Pushpadass HA, Sivaram M, Ramesha KP, Das DN, Kataktalware MA, Prakash MA, Kumar, RD (2016). Infrared thermography: A poten- 
tial noninvasive tool to monitor udder health status in dairy cows. Veterinary World 9(10): 1075.

Sathiyabarathi M, Jeyakumar S, Manimaran A, Pushpadass HA, Sivaram M, Ramesha KP, Das DN, Kataktalware, MA (2018). Infrared thermal imaging of udder skin surface temperature variations to monitor udder health status in Bos indicus (Deoni) cows. Infrared Physics \& Technology88: 239-244.

Schukken YH, Wilson DJ, Welcome F, GarrisonTikofsky L, Gonzalez RN (2003). Monitoring udder health and milk quality using somatic cell counts. Veterinary research 34(5): 579-596.

Sharif A, Umer M, Muhammad G (2009). Mastitis control in dairy production. Journal of Agriculture Social Sciences 5: 102-105.

Shitandi A, Kihumbu G (2004). Assessment of the California mastitis test usage in smallholder dairy herds and risk of violative antimicrobial residues. Journal of Veterinary Science 5(1): 5-10.

Stajnko D, Brus M, Hočevar M (2008). Estimation of bull live weight through thermographically measured body dimensions. Computers and Electronics in Agriculture 61(2): 233-240.

Stajnk D, Vindis P, Berk P (2010). Estimation of bull live weight using thermal imaging. DAAAM International Scientific Book 227-237.

Stewart M, Webster JR., Schaefer AL, Cook NJ, Scott SL (2005). Infrared thermography as a non-invasive tool to study animal welfare. Animal Welfare 14(4): 319-325.
Stokes JE, Leach KA, Main DCJ, Whay HR (2012). An investigation into the use of infrared thermography (IRT) as a rapid diagnostic tool for foot lesions in dairy cattle. The Veterinary Journal 193(3): 674678.

Talukder S, Kerrisk KL, Ingenhoff L, Thomson PC, Garcia SC, Celi P (2014). Infrared technology for estrus detection and as a predictor of time of ovulation in dairy cows in a pasture-based system. Theriogenology 81(7): 925-935.

Tangorra FM, Redaelli , Luzi F, Zaninelli M (2019). The use of infrared thermography for the monitoring of udder teat stress caused by milking machines. Animals 9(6): 384.

Unruh EM, Theurer ME, White BJ, Larson RL, Drouillard JS, Schrag N (2017). Evaluation of infrared thermography as a diagnostic tool to predict heat stress events in feedlot cattle. American Journal of Veterinary Research 78(7): 771-777.

Uzmay C, Kaya İ, Akbaş Y, Kaya A (2003). Effects of udder and teat morphology, parity and lactation stage on subclinical mastitis in holstein cows. Turkish Journal of Veterinary and Animal Sciences 27(3): 695-701.

Yağcı İP (2008). Subclinical mastitis in sheeps; etiology, epidemiology and diagnosis methods. Journal of the Faculty of Veterinary Medicine, Kafkas University. 14(1): 117-1. 